BIOINFORMATICS

\title{
Cobalt- and Nickel-containing enzyme constructs from the sequences of methanogens
}

\author{
P. Chellapandi, J. Balachandramohan
}

Department of Bioinformatics, School of Life Sciences, Bharathidasan University Tiruchirappalli-620024, Tamil Nadu, India

pchellapandi@gmail.com

\begin{abstract}
Aim. The conserved domain of sequences revealed in methanogens is considered for designing enzymes among which the attention has been focused on the metalloenzymes showing evolutionary significances. Methods. Molecular evolution, molecular modelling and molecular docking methods. Results. Molecular evolutionary hypothesis has been applied for designing cobalt-containing sirohydrocholine cobalt chelatase and nickel-containing coenzyme $F_{420}$ non-reducing hydrogenase from conserved domains encompassing metal-and substrate-binding sites. It was hypothesized that if any enzyme has similar or identical conserved domain in its catalytic region, the construct can bring similar catalytic activity. Using this approach, the region which covers such functional module has to be modeled for yielding enzyme constructs. The present approach has provided a high likelihood to design stable metalloenzyme constructs from the sequences of methanogens due to their low functional divergence. The resulted enzyme constructs have shown diverse reaction specificity and binding affinity with respective substrates. Conclusions. It seems to provide a new knowledge on understanding the catalytic competence as well as substrate-specificity of enzyme constructs. The resulted enzyme constructs could be experimentally reliable as the sequences originally driven from methanogenic archaea.
\end{abstract}

Keywords: molecular docking, metalloenzymes, conserved domains, molecular evolution, enzyme design, enzyme constructs.

Introduction. Enzymatic or microbial transformations are environmental friendly, clean process and useful means for obtaining biologically important compounds. Enzymes from nature rarely have the combined properties necessary for the industrial fine chemical production that will be present over the course of a manufacturing process. Enzymes from extremophilic organisms may provide useful biocatalysts and may be even more valuable for biotransformation reactions. A range of methanogenic archaeon enzymes application and usage of the organisms themselves in biotechnology are more restricted. At present, many studies explore the identification of novel enzymes from methanogens for the industrial application $[1,2]$.

Metals are tightly bound in the active sites of metalloenzymes to bring the chemical activity. The metalloenzymes are potentially very good models for desig-

(C) Institute of Molecular Biology and Genetics, NAS of Ukraine, 2012 ning chemical catalysts. The first step towards designing a working catalyst is, therefore, knowledge on the structure of the enzyme and its active site [2,3]. Evolutionary conservation in sequence and structure would make contribution in enzyme catalysis. Such conserved amino acid residues are major concern in designing metalloenzymes.

Upon designing enzyme constructs, the molecular evolution of enzymes is playing a crucial role in biological systems when enzymes are in action $[4,5]$. Thus, the present study describes the application of a molecular evolutionary hypothesis to design metalloenzymes constructs from conserved domains in the sequences of methanogens encompassing metal- and substrate-binding sites.

Materials and methods. Evolutionary conservation analysis of metalloenzymes. Complete protein sequences of archaeal cobalt and nickel-containing enzymes were retrieved from GenPept of NCBI. Conser- 
ved domains architecture of these sequences was searched in NCBI-Conserved Domain Database (CDD). The metal binding sites of the sequences were identified from availed PDB structures using the corresponding PSSM ID in NCBI-CDD. A position-specific score matrix prepared from the underlying conserved domain alignment was compared with the query sequences. Multiple sequence alignment of the selected sequences was performed by ClustalX 2.0 software [6], in which aligned sequences were manually inspected to delete the low scoring sequences. After that, the neighbor joining phylogenetic tree was constructed by MEGA 4.0 software [7] with 1000 bootstraps values.

Molecular modelling and enzyme designing. Homology modelling was carried out by ModWeb, an automatic comparative protein modelling server, from query sequences obtained from methanogens [8]. A suitable PDB template for homology modelling was identified with PSI-BLAST tool [9] by searching against PDB database. ProFunc server [10] was used to predict the corresponding function sites of models. The catalytic domains of every protein model were compared with the crystallographic protein structures. Amino acid residues encompassing the sites for metal-binding and substrate-binding regions were removed from atomic coordinates of a protein model and subjected to further homology modelling. Prime program in Maestro software package (Schrodinger Inc.) was used to build the homology models from the above selected regions and then evaluated with Structural Analysis and Verification Server (SAVS) (http://nihserver.mbi.ucla.edu/SAVES/). The best scoring models were superimposed on the corresponding PDB template by DALITE server (http:// ekhidna.biocenter.helsinki.fi/dali_lite/start). Standard dynamics simulation cascade module in Discovery Studio software with CHARMM force field, steepest descent and adopted basis Newton-Raphson algorithms was used for generating structural conformers of each model. Conformers were typically created for molecules that have a small number of alternate locations for a small subset of the atoms. Distance constraint of each model was fixed between $\mathrm{N}$-terminal to $\mathrm{C}$-terminal, and dihedral restraint was started from $\mathrm{C}$ to $\mathrm{C} \alpha(\Phi)$ of first amino acid residue and $\mathrm{C} \alpha$ to $\mathrm{N}(\psi)$ of second amino acid residue until the last amino acid residue in a molecular dynamic ensemble.
Molecular docking of enzyme construct-substrate complex. Substrate structures were retrieved from KEGG database with SIMCOM tool (http://www.genome.jp/ tools/simcomp) and then molecular formats prepared as PDB format for molecular docking studies. Homology models resulted from Prime program was prepared with charges for molecular docking studies. Both substrate and protein were treated with AMBER force field implemented in AutoDock 4.0. software. Ligand Fit docking was conducted by AutoDock software with Genetic Algorithm and computed inhibition constant, binding energy and other molecular forces of resulted docking models. Active site residues in enzyme construct as in energy grid were allowed to interact with substrate. After docking, enzyme-substrate complex was solvated with explicit periodic boundary solvation model. The quality of each docking model was checked by AutoDock scoring system and graphically represented by PyMOL software.

Results and discussion. Designing sirohydrocholi ne cobalt chelatase. Cobaltochelatase, methionine synthase, methionine aminopeptidase, methylmalonyl-CoA mutase and methyl aspartate mutase are cobalt-dependent enzymes identified in the genomes of archaea. Among these, sirohydrocholine cobaltochelatase (SHCCC) and anaerobic chelatase (ACC) are present in methanogens. The limited structural information is available for cobalt chelatase in the PDB to date. The sequence identity of SHCCC is ranged from $30-46 \%$ with PDB templates. Enzyme sequences under accession numbers $\mathrm{YP}_{-}$ 001098022 (construct 1) from Methanococcus maripaludies C5 and YP_001030522 (construct 2) from $\mathrm{Me}$ thanocorpusculum labreanum $\mathrm{Z}$ have significant modelling scores, and encompassed the shortest metal binding sites incorporating functional region (Supplementary). Aligned SHCCC sequences have also more conservation at the substrate- and metal-binding regions (Fig. 1). Construct 1 is evolutionarily related only to closely related species of the same genera and its function may conserve in the particular sequence position and/or domain. SHCCC in M. labreanum Z shows more evolutionary relationship with SHCCC of M. maripaludies C5 (bootstrap value 987-1000) than with other archaea. The different species of Methanosarcina genus are clustered with the members in the genus of Methanococcus in the first clade, and then both of them 


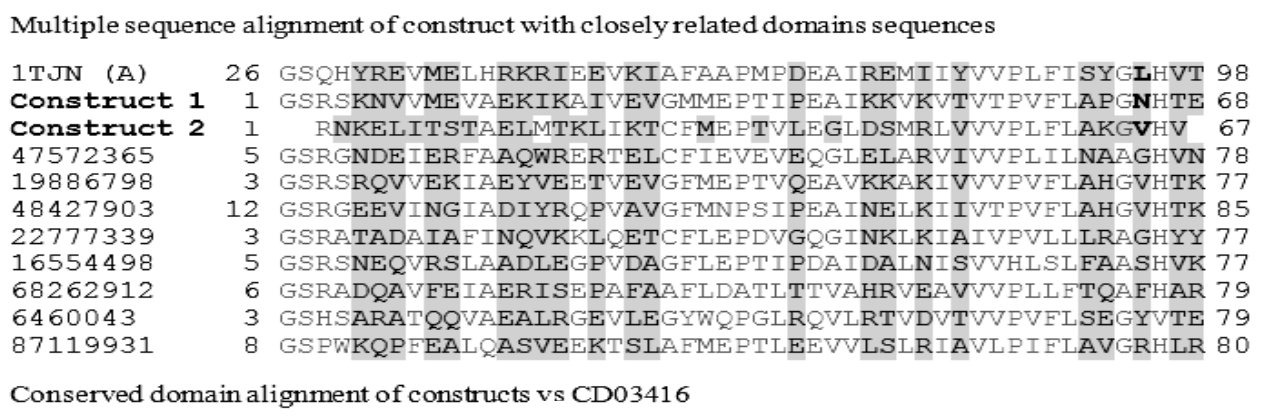

Construct 11 GSRIPHSRNVVMEVAERIRARGIYDIVEVGMMEFNEPTIPEAIKRVIDAGARKVTVTPVHIAPGNHTE 68 CD03416 8 GSRDPRAAEALEALAERLRERIPGDEVELAFLELAEPSLAEALDELAAQGATRIVVVPLFLIAGGHVK 75 Construct 21 RLNYNREIITSTAELMTRRTDEYLIRTCEMENCSPTVLEGLDSMRTEDIDRIVVVPIFIARGVHV 74

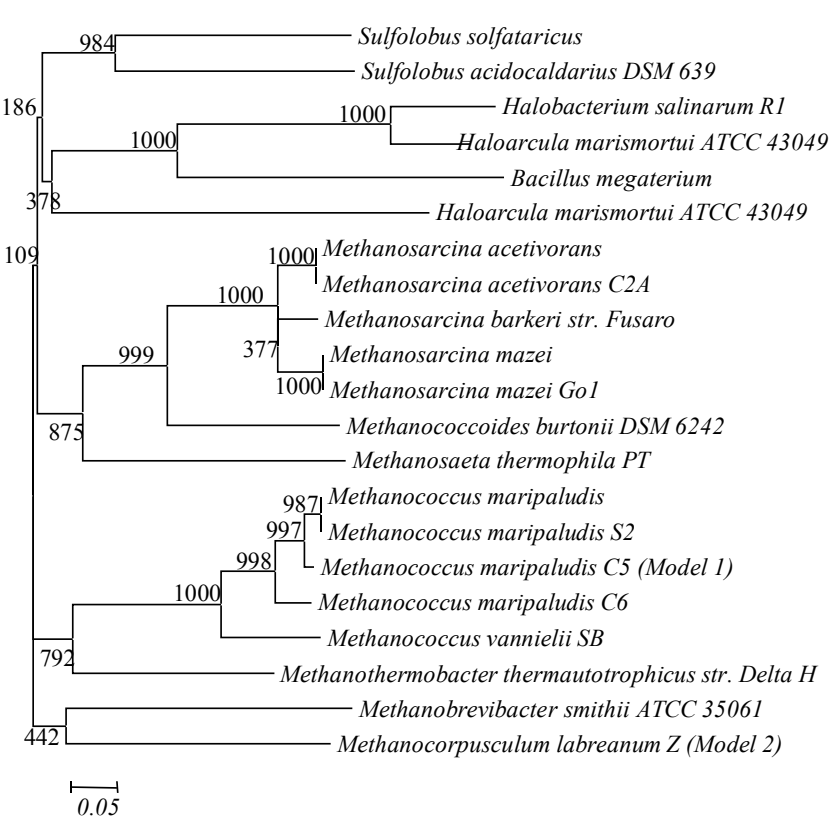

Fig. 2. Phylogenetic tree of SHCCC sequences obtained from methanogens and closely related organisms

formed second clade having organisms belonged to the groups of halophilic and sulfur reducing archaea (Fig. 2). As the results of phylogenetic analysis, evolutionbased approach provides a high likelihood to design metalloenzymes.

Construct 2 is slightly better than construct 1 as it has the lowest binding energy $(-9.79 \mathrm{kcal} / \mathrm{mol})$. Both enzyme constructs are opted for catalytic conversion uroporphyrin I and precorin-2-dihydro sirohydrochlorin to the respective products (Table). The most important interactions contributing to the high binding affinity are six H-bonds between the carbonyl group of sirohydrochlorin and the side chains of His09, Leu70, Arg12 and Ser16 in construct 1 . The possible interaction sites are: O2-His09 (3.10 ̊), O15-Leu70 (2.93 Å),
O7-Ser16 (2.96 ̊̊), O11-Arg12 (3.19 ̊̊), O5-Arg12 (2.78 $)$, and O5-Arg12 (3.38 $)$. Among these, Arg 12 forms three H-bonds to confer higher binding affinity. Six H-bonds are formed between sirohydrochlorin and construct 2 at atomic positions of H3-Ser13 (2.52 $\AA$ ),

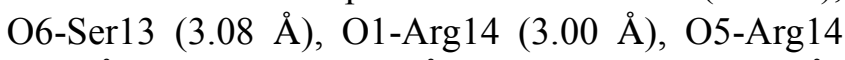

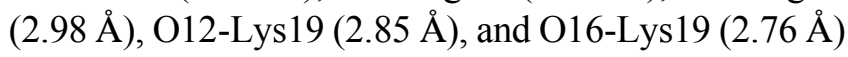
(Supplementary).

Designing coenzyme $F_{420}$ non-reducing hydrogenase. Archaeal genomes have consisted of 6 cobalt containing enzymes include coenzyme $\mathrm{F}_{420}$ hydrogenase, methyl coenzyme $\mathrm{M}$ reductase, hydrogenase maturation protease, carbon monoxide dehydrogenase, rubredoxin, urease, acetyl-CoA decarbonylase/synthase complex. Coenzyme $\mathrm{F}_{420}$ hydrogenase has two types of enzyme modules, such as coenzyme $\mathrm{F}_{420}$-reducing hydrogenase and coenzyme $\mathrm{F}_{420}$-non-reducing hydrogenase (CFNRH). As similar to SHCCC, no crystallographic structures of these enzymes in the PDB are opted for enzyme designing. The protein sequence of Methanosarcina acetivorans $\mathrm{C} 2 \mathrm{~A}$ under accession number $\mathrm{NP}_{-}$ 616085 (construct) is suited on designing CFNRH construct (Supplementary). As compared to coenzyme $\mathrm{F}_{420^{-}}$ reducing hydrogenase and non-reducing hydrogenase, hydrogenase maturation protease is distantly related for its function. CFNRH of this study is phylogenetically resembled to coenzyme $\mathrm{F}_{420}$-reducing hydrogenase of other methanogens (Fig. 3). It pointed out that coenzyme $\mathrm{F}_{420}$-reducing hydrogenase (hysF) and hydrogenase maturation protease (hycI) are distinctly produced monophyletic clades in the phylogenetic tree. There are separate sub-clusters for the species of all genera including Methanococcus, Methanosacina, Methanospirillum and thermophilic archaea in 


\begin{tabular}{|c|c|c|c|c|}
\hline Substrates & Binding energy, $\mathrm{kcal} / \mathrm{mol}$ & Inhibition constant, $\mathrm{mM}$ & Intermolecular energy, $\mathrm{kcal} / \mathrm{mol}$ & Internal energy, $\mathrm{kcal} / \mathrm{mol}$ \\
\hline \multicolumn{5}{|c|}{ Sirohydrochlorin cobaltochelatase } \\
\hline \multicolumn{5}{|l|}{ Construct 1} \\
\hline Sirohydrochlorin & -9.60 & $0.09 *$ & -10.08 & -7.76 \\
\hline Siroheme & -6.54 & 0.02 & -10.44 & -9.98 \\
\hline Uroporphyrin I & -9.04 & $0.24 *$ & -9.96 & -8.98 \\
\hline Uroporphyrin III & -7.65 & $2.48^{*}$ & -8.55 & -7.83 \\
\hline Coproporphyrin III & -2.89 & 7.59 & -5.97 & -4.56 \\
\hline $\begin{array}{l}\text { Precorin-2-dihydro } \\
\text { sirohydrochlorin }\end{array}$ & -8.65 & $0.45^{*}$ & -8.83 & -7.76 \\
\hline \multicolumn{5}{|l|}{ Construct 2} \\
\hline Sirohydrochlorin & -9.79 & $0.07 *$ & -10.09 & -6.35 \\
\hline Siroheme & -6.06 & 0.04 & -9.89 & -9.49 \\
\hline Uroporphyrin I & -9.48 & $0.11 *$ & -10.19 & -8.66 \\
\hline Uroporphyrin III & -8.72 & $0.40 *$ & -9.68 & -6.95 \\
\hline Coproporphyrin III & -4.12 & 0.95 & -7.06 & -4.59 \\
\hline $\begin{array}{l}\text { Precorin-2-dihydro } \\
\text { sirohydrochlorin }\end{array}$ & -9.58 & $0.09 *$ & -9.94 & -6.63 \\
\hline \multicolumn{5}{|c|}{ Coenzyme $F_{420}$ non-reducing dehydrogenase } \\
\hline \multicolumn{5}{|l|}{ Construct } \\
\hline Reduced coenzyme $\mathrm{F}_{420}$ & -4.81 & 0.30 & -10.11 & -8.80 \\
\hline THF-L-glutamate & -3.44 & 3.01 & -8.64 & -7.39 \\
\hline Reduced FMN & -5.07 & 0.19 & -4.80 & -4.50 \\
\hline $\begin{array}{l}\text { 10-Formyltetrahydrofo- } \\
\text { lyl-L-glutamate }\end{array}$ & -4.31 & 0.70 & -9.08 & -7.03 \\
\hline
\end{tabular}

*Inhibition constant is expressed as $\mu \mathrm{M}$.

which many of the hydrogenases belonging to Methanococcus genus. It may functionally diverge into $\mathrm{NiFe}-$ hydrogenase maturation protease of Candidatus $\mathrm{Ko}$ rarchaeum cryptofilum OPF8 (Fig. 4).

Enzyme construct has shown strong interactions with reduced FMN. It is also supported by computing inhibition constant $(38.58 \mu \mathrm{mol})$ of reduced FMN as shown in Table 1. Intermolecular energy of constructreduced coenzyme $\mathrm{F}_{420}$ complex is $-12.26 \mathrm{kcal} / \mathrm{mol}$. A strong binding affinity is observed in enzyme construct-reduced FMN wherein two H-bonds formed between the side chains of Lys80 and Ala86 and reduced FMN. The possible interaction sites are: O1-Lys 80 (2.97 $\AA$ ) and O6-Ala86 (2.88 ̊̊) (Supplementary).
The single conserved domain (CbiX_SIR_B_N of chelatase class II superfamily) is detected in SHCCC sequences of M. maripaludies and M. labreanum $\mathrm{Z}$ that may catalyze biochemical reactions. A divergent evolution occurred among cobalt and nickel metabolisms due to more ancestral similarities of cobaltchelatase as reported earlier [11]. Cobaltochelatase of archaeal domain has shown more phylogenetic similarity with CbiX of Bacillus megaterium [12]. Similarly, the phylogenetic analysis in this study revealed a phylogenetic resemblance between methanogens and $B$. megaterium for SHCCC sequences. It also closely related to halophilic archaea. CbiX tolerates large sequence rearrangements in four out of the nine loop regions of the SHCCC. 
Multiple sequence alignment of construct with closely related domains sequences

$\begin{array}{lrlr}\text { 1CFZ_A } & 4 & \text { GVRIVEALEVEILDGGTGMELLGDMHLIIADAPGTMMILREEVPALHQL } & 145 \\ \text { Construct } & 1 & \text { GLKVIEALKLDIADAGVGLDLLNLFKVIIVDAKGSVHRIERDLIEGHTL } & 76 \\ 72537510 & 3 & \text { GVIIAQRLQVRIFDCGTGMEVMFQAQLIILDAPGAVFEVPSELEQLHDF } & 147 \\ 89091973 & 4 & \text { GWLLVDMLEAERINISAGAELFAVLQIVVVDAPGEFRFIAAELLGSHTL } & 138 \\ 117924193 & 15 & \text { GPWLVAQLQWLRDLGTLLGIANHTTLLVVDAVGQWRAYGGEVAGVHQL } & 155 \\ 126436004 & 5 & \text { GPAVASAVDVRVLSVADPCAILDAWLAVVIDAPGRIHRCADQLPASHAV } & 142 \\ 120602293 & 5 & \text { GVFAAQELMVTIMEAGTTQDIFYLFALLVLDIPGTIYRLSEDLVQKHDI } & 145 \\ 157404343 & 14 & \text { GVRCIERLSVELYDGGTAMDLLDVIKMFILDAPGMIYRFREDIKTEHQM } & 153 \\ 144898858 & 4 & \text { GVHAVTALAVEIIDGGTGMDCLDRILLLIADCPGDITRLADQINAWHQV } & 145 \\ 118746433 & 5 & \text { GPKVIEQLQVVLLDGGTGDLLPHLRLIIVDAAGSCVRLADEVPMAHQM } & 145\end{array}$

Conserved domain alignment of construct vs CD00518

Construct 1 GLKVIEALKktELDELDGLDIADAGVCGLDLLNLFDGASKVIIVDAVLTGNRKGSVHRIEGRDLIEGTE---PHTL 73 CD00390 16 GPAVAERLE--ERYLPPGVEVIDGGTLGLELLDLLEGADRVI IVDAVDSGGE PGTVRRLEPEELPAYLSAISTHQL 89
Fig. 3. Functional features of CNFRH enzyme constructs computed by multiple sequence alignment (Shaded regions show the highly variable amino acids and bolded regions represent functional amino acids)
These rearrangements may serve as starting points for the evolution of new functions (binding of new substrates) [13]. It suggested that conservations of enzyme function are not deviated at sequence level, and its catalytic function evolved from the structural features, particularly loop regions of these constructs. Thus, the present approach is more convenient for designing an enzyme even from its sequence in appropriate manner. Glu264 and His183 are mechanistically the most critical residues for catalytic activity and form the active site in conjunction with residues that selectively bind the tetrapyrrole substrate in accordance with the earlier reports $[14,15]$. The results from molecular mechanics studies implied that conformational free energies of our enzyme constructs are more stable. Hence, the structures of these constructs have to show low degree of freedoms to recognize sirohydrochlorin specificity, which is rather than other tetrapyrrole substrates (Supplementary).

Removal of two protons followed by insertion of the cobalt ion induces planarity into macrocycle, resulting in its exclusion from the active site [16]. Thus, sirohydrochlorin is bent such that two pyrrole nitrogens are orientated towards the active site histidine for its binding with SHCCC. Similarly, sirohydrochlorin stably interacts with the side chains of His09, Leu70, Arg12 and Ser16 in construct 1 and Ser13 and Arg14 in construct 2. A strong interaction is found between construct 1 and sirohydrochlorin in the side chain of Arg12. At Ser13 and Arg14 residues, construct 2 forms a complex with sirohydrochlorin. It indicates that either Ser13 or Arg12 could serve as active region providing catalytic function to these constructs. Towards the C- terminal end of $\mathrm{CbiX}$, the histidine rich region is likely to act as a cobalt store or could interact directly with the cobalt transport system to allow direct transfer of the metal ion from the import system to its site of action. Construct 1 has more numbers of histidine residues, some of which contributed for H-bonding with sirohydrochlorin in accordance to the earlier report [17].

There is no common agreement on the catalytic mechanism of Ni-Fe hydrogenase. The sequences of CFNRH from $M$. acetivorans consisted of $\mathrm{H} 2 \mathrm{MP}$ domain assigning function to hydrogenase specific C-terminal endopeptidases. Phylogenetic analysis in this study also supported its functional divergence with $\mathrm{NiFe}$-hydrogenase maturation protease of Candidatus Korarchaeum cryptofilum $\mathrm{OPF} 8 . \mathrm{H}_{2} \mathrm{MP}$ domain may be originated from subsequent functional divergence during evolution. The maturation of FeNi-hydrogenases includes the formation of nickel metallocenter, proteolytic processing and assembly with other subunits. The hydrogenase maturation endopeptidases are responsible for the proteolytic processing, liberating a short C-terminal peptide by cleaving after His or Arg residue. This cleavage is nickel dependent. Similarly, in this study a strong binding affinity is observed between individual atoms of reduced FMN and the side chains of enzyme construct. It reflects the en zyme mimics as similar to hydrogenase maturation endopeptidases by cleaving His87 or Arg84 residue in the C-terminal. Based on DFT studies, Pavlov et al. proposed a mechanism stating the resting state of the dinuclear cluster is $\mathrm{Ni}$ (II) $\mathrm{Fe}$ (III); $\mathrm{H}_{2}$ first binds to Fe in the form of a molecular hydrogen complex, which then undergoes heterolytic splitting [18]. Hydride transfer 


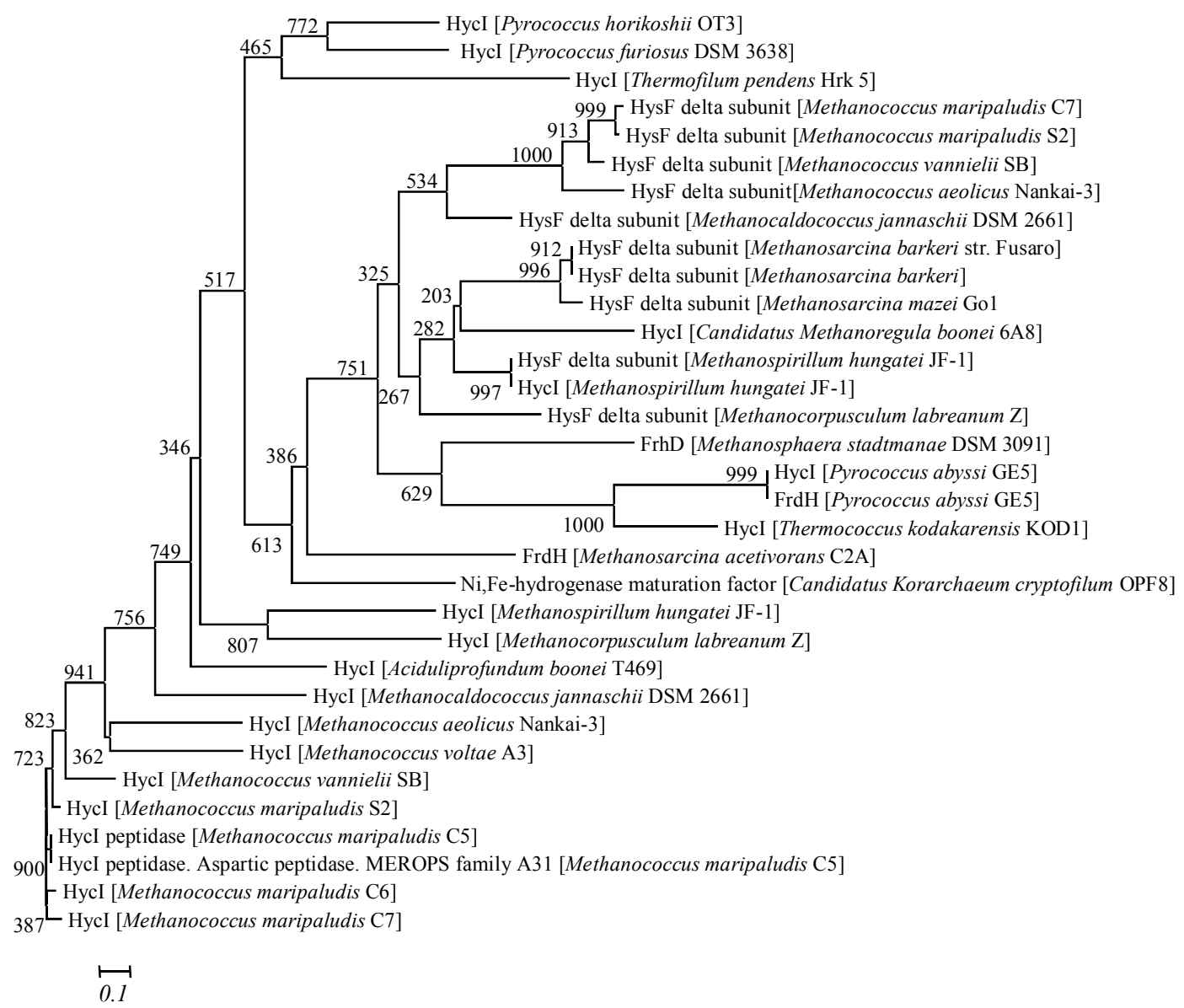

Fig. 4. Phylogenetic tree of CNFRH sequences obtained from methanogens and closely related organisms to $\mathrm{Fe}$ and proton transfer to the adjacent Cys thiolate ligand is accompanied by decoordination of the protonated Cys thiol from $\mathrm{Ni}$ whi le remaining bound to $\mathrm{Fe}$. The cyanide ligand on Fe simultaneously binds with the $\mathrm{Ni}$ atom in a bridging binding mode. After the $\mathrm{H}_{2}$ dissociation, the hydride bound to Fe can then be transferred to Ni which should be a necessary preliminary for subsequent $\mathrm{H}^{+}$or electron transport. Accordingly, oxidation of molecular hydrogen could be mediated by CFNRH construct on reduced FMN. A strong phylogenetic correspondence of these enzyme constructs only to other closely related methanogens implied its evolutionary conservation.

Similar approach has already been reported for designing $\beta$-methylaspartate mutase [3] and formyltetrahydrofolate ligase [5] from the sequences of archaea [19]. Similar to that, we have not done any alternation in native amino acids position or replacing residues, and, thus, it is directly based on the conserved domain of metalloenzymes.
Acknowledgements. The first author is thankful to the University Grants Commission, New Delhi, India, for financial assistance (32-559/2006) to carry out the work.

П. Челлапанді, Дж. Балачандрамохан

Кобальт- і нікель-вмісні ферментні конструкції із послідовностей метаногенів

Резюме

Мета. Використати консервативний домен, отриманий із послідовностей метаногенів, для конструювання ферментів. Особливу увагу приділено металоферментам, оскільки вони мають важливе еволюиійне значення. Методи. Теорія молекулярної еволюиії, методи молекулярного моделювання і молекулярного докінгу. Результати. Конструювання кобальт-вмісної кобальтової хелатази і нікель-вмісного коферменту $F_{420}$ нередукиійної гідрогенази із консервативних доменів, оточуючих метал- $і$ субстрат-зв 'язувальні сайти, здійснено на основі теорії молекулярної еволюиії. Зроблено припущення стосовно того, що якщо будь-який фермент містить у своєму каталітичному сайті схожий або ідентичний консервативний домен, то конструкиії може бути притаманна подібна каталітична активність. Використовуючи цей nідхід для створення ферментної конструкиії, потрібно змоде- 
лювати ділянку, яка включає такий функціональний модуль. Даний метод забезпечує високу вірогідність одержання стабільних металоферментних конструкиій із послідовностей метаногенів через їхню низьку функиіональну дивергенцію. Ферментні конструкції проявили різну реакційну специфічність і спорідненість при зв'язуванні з відповідними субстратами. Висновки. Очевидно, щзо будуть отримані нові знання для розуміння каталітичної спроможності, а також субстрат-специфічності ферментних конструкиій. Одержані ферментні конструкиії можна застосовувати в експериментах як послідовності, щяо походять від метаногенної археї.

Ключові слова: молекулярный докінг, металоферменти, консервативні домени, молекулярна еволюиія, ферментний дизайн, ферментні конструкиіі.

\section{П. Челлапанди, Дж. Балачандрамохан}

Кобальт- и никель-содержащие ферментные конструкции из последовательностей метаногенов

\section{Резюме}

Цель. Использовать консервативный домен, полученный из последовательностей метаногенов, для конструирования ферментов. Особое внимание уделено металлоферментам, поскольку они имеют важное эволюиионное значение. Методы. Теория молекулярной эволюиии, методы молекулярного моделирования и молекулярного докинга. Результаты. Конструирование кобальт-содержащей кобальтовой хелатазы и никель-содержащего кофермента $F_{420}$ нередукционной гидрогеназы из консервативных доменов, окружающих металл- и субстрат-связывающие сайты, осуществлено на основе теории молекулярной эволюичи. Сделано предположение о том, что если какой-либо фермент содержит в своем каталитическом сайте похожий или идентичный консервативный домен, то конструкиия может обладать подобной каталитической активностью. Используя этот подход для создания ферментной конструкции, нужно моделировать участок, включаюший такой функииональный модуль. Данный метод обеспечивает высокую вероятность получения стабильных металлоферментных конструкций из последовательностей метаногенов вследствие их низкой функииональной дивергенции. Ферментные конструкции проявляют различную реакционную специфичность и сродство при связывании с соответствующими субстратами. Выводы. Вероятно, будут получены новые знания для понимания каталитической способности, а также субстрат-специифичности ферментных конструкций. Полученные ферментные конструкиии можно использовать в экспериментах как последовательности, происходящие от метаногенной археи.

Ключевые слова: молекулярный докинг, металлоферменты, консервативные домены, молекулярная эволюиия, ферментный дизайн, ферментнье конструкиии.

\section{REFERENCES}

1. Luetz S., Giver L., Lalonde J. Engineered enzymes for chemical production // Biotechnol. Bioeng.-2008.-101, N 4.-P. 647653.

2. Alqueres S. M. C., Almeida R. V., Clementino M. M., Vieira R. P., Almeida W. I., Cardoso A. M., Martins O. B. Exploring the biotechnological applications in the archaeal domain // Braz. J. Microbiol.-2007.-38, N 3.-P. 398-405.

3. Chellapandi P., Balachandramohan J. Molecular evolution-directed approach for designing of $\beta$-methylaspartate mutase from the sequences of Haloarchaea // Int. J. Chem. Mod.-2011.-3, N 3.-P. 143-154.

4. Schenk S., Weston S., Anders E. Computational studies on the mode of action of metalloenzymes - quantum chemistry connects molecular biology with chemistry // Berichte des IZWR.2003.-2.-P. 1-18.

5. Chellapandi P., Balachandramohan J. Molecular evolutiondirected approach for designing archaeal formyltetrahydrofolate ligase // Turk. J. Biochem.-2011.-36, N 2.-P. 122-136.

6. Thompson J. D., Gibson T. J., Plewniak F., Jeanmougin F., Higgins $D$. G. The CLUSTAL_X windows interface: flexible strategies for multiple sequence alignment aided by quality analysis tools // Nucleic Acids Res.-1997.-25, N 24.-P. 4876-4882.

7. Tamura K., Dudley J., Nei M., Kumar S. MEGA4: Molecular Evolutionary Genetics Analysis (MEGA) software version 4.0 // Mol. Biol. Evol.-2007.-24, N 8.-P. 1596-1599.

8. Eswar N., John B., Mirkovic N., Fiser A., Ilyin V. A., Pieper U., Stuart A. C., Marti-Renom M. A., Madhusudhan M. S., Yerkovich $B$., Sali $A$. Tools for comparative protein structure modeling and analysis // Nucleic Acids Res.-2003.-31, N 13.P. 3375-3380.

9. Altschul S. F., Madden T. L., Schaffer A. A., Zhang J., Zhang Z., Miller W., Lipman D. J. Gapped BLAST and PSI-BLAST: a new generation of protein database search programs // Nucleic Acids Res.-1997.-25, N 17.-P. 3389-3402.

10. Laskowski R. A., Watson J. D., Thornton J. M. ProFunc: a server for predicting protein function from 3D structure // Nucleic Acids Res.-2005.-33, Web Server issue.-P. W89-W93.

11. Brindley A. A., Raux E., Leech H. K., Schubert H. L., Warren M. $J$. A story of chelatase evolution: identification and characterization of a small 13-15-kDa «ancestral» cobaltochelatase (CbiXS) in the archaea // J. Biol. Chem.-2003.-278, N 25.-P. 2238822395.

12. Gerlt J. A., Babbitt P. C. Divergent evolution of enzymatic function: mechanistically diverse superfamilies and functionally distinct suprafamilies // Annu. Rev. Biochem.-2001.-70.-P. 209246.

13. Raux E., Thermes C., Heathcote P., Rambach A., Warren M. J. A role for Salmonella typhimurium cbiK in cobalamin (vitamin B12) and siroheme biosynthesis // J. Bacteriol.-1997.-179, N 10.-P. 3202-3212.

14. Al-Karadaghi S., Franco R., Hansson M., Shelnutt J. A., Isaya G., Ferreira G. C. Chelatases: distort to select? // Trends Biochem. Sci.-2006.-31, N 3.-P. 135-142.

15. Pisarchik A., Petri R., Schmidt-Dannert C. Probing the structural plasticity of an archaeal primordial cobaltochelatase $\mathrm{CbiX}$ (S) // Protein Eng. Des. Sel.-2007.-20, N 6.-P. 257-265.

16. Dailey H. A., Dailey T. A., Wu C. K., Medlock A. E., Wang K. F., Rose J. P., Wang B. C. Ferrochelatase at the millennium: structures, mechanisms and [2Fe-2S] clusters // Cell. Mol. Life Sci.2000.-57, N 13-14.-P. 1909-1926.

17. Leach M. R., Zhang J. W., Zamble D. B. The role of complex formation between the Escherichia coli hydrogenase accessory factors HypB and SlyD // J. Biol. Chem.-2007.-282, N 22.P. 16177-16186.

18. Pavlov M., Siegbahn P. E. M., Blomberg M. R. A., Crabtree R. $H$. Mechanism of $\mathrm{H}-\mathrm{H}$ activation by nickel-iron hydrogenase // J. Am. Chem. Soc.-1998.-120, N 3.-P. 548-555.

19. Chellapandi $P$. Molecular evolution of methanogens based on their metabolic facets // Front. Biol.-2011. DOI 10.1007/s11515011-1154-2. 